\title{
Alternative Lesson Design of Basic Chemistry Learning to Integrate Green Chemistry Principles as View of Scientific Character Values
}

\author{
Mitarlis*, Utiya Azizah, Bertha Yonata \\ Departement of Chemistry, Universitas Negeri Surabaya \\ Surabaya, Indonesia \\ mitarlis@unesa.ac.id
}

\begin{abstract}
This Actual global problem in this time is decreasing of environment quality. Some effort had been done to solve this problem as well as through education by designing lesson as an alternative to implement green chemistry principles. The aims of this study that discussed in this article were; 1) analyze the principles of green chemistry as wiew of scientific character values on basic chemistry subject, 2) develop learning design of basic chemistry subject by integrating green chemistry as wiew of scientific character values. The first stage by analyzing previous research use systematic review method. The previous studies were analyzed that related to green chemistry, green engineering, character education, and green education, as well as analysis of Basic Chemistry lecture document. In conclusion the lesson design show that; 1) the several of green chemistry principles can be integrated on Basic Chemistry lecture, were: waste prevention, efficiency of energy, renewable feedstock using, degradation design, real-time analysis for prevention of pollution and always create the safer condition in chemicals using for to prevent accident; 2) Scientific character values with green chemistry insight are: honest, conscientious, curiosity, care for the environment, thrifty and creative. Implementation of the principles of green chemistry as view of scientific character values on Basic Chemistry subject can be implemented with alternative learning model such as Project Based Learning by giving the project tasks to the students.
\end{abstract}

Keywords—green chemistry, green education, learning design

\section{INTRODUCTION}

Decreasing of environment quality being crucial and actual global problem worldwide in this time. The environmental degradation in the world are in an alarming level [1]. Therefore, understanding and action to minimize the influence the behavior and attitudes of individuals towards the environment needs to get attention. It is inevitable that the various environmental problems that occurred at this time caused by human activity. This happens due to lack of knowledge about the environment or due to a less responsible attitude and do not care about the environment. Discussing about environmental problems and efforts to overcome related to the popular term lately is "green". Many things associated with green, for example, the slogan "go green", green school $[2,3,4]$ green computing [5], green technology [6], green chemistry [1], green education $[7,8]$, and others.
Manahan S.E., (2006) stated the practice of green chemistry based on the Environmental Chemistry. Green Chemistry is a concepts or philosophy wich drive a product or processes designing of a product or processes to reduce or eliminate the dangerous substances using and production. The Green Chemistry concept itself is derived from some branch of chemistry such as Biochemistry, Organic, Inorganic and Analitical Chemistry. However, the concept was likely to lead to implementation in the industrial field. Should be emphasized that Green Chemistry is different from the Environmental Chemistry. Green Chemistry concept is more focused on efforts to minimize the come up of dangerous substances and maximize the efficiency of the chemicals using. Meanwhile, the Environmental Chemistry more emphasis on environmental phenomenon that has been polluted by chemical substances [9]. Chemicals using frequenly involved in laboratory activities that are less friendly to the environment. Green Chemistry necessary tips to apply the principles of green chemistry [10].

This article present the results of research on the analysis and implementation of the green chemistry principles, particularly related to the scientific behavor/character values with green chemistry insight. Education of character is frequently associated with behavioral or moral attitude, but actually it is more than behavior or moral attitude only. There were appoximately 100 character values have been identified based on the wider range of character that can be selected and developed in the character education implementation. Identified character values such as the related to obligations towards God, communities and nations, their families, themselves, as well as obligations to keep the nature and the environment[11]. It had been identified the green chemistry principles that can underlie scientific character values with green chemistry insight [12]. Environmental problems are also associated with moral issues and human behavior problems. Higher education as a continuation and culmination of the educational process in the formal education clearly has a role and responsibility in strengthening the nation character building which has been built and developed since basic education 
Based on previous research, the real step integration of the scientific character values of characters in each learning in universities, particularly in the Department of Chemistry, Universitas Negeri Surabaya [13]. In realizing this, also encountered obstacles due to the integration of character values is not visible and explicitly conveyed to students. Of the 18 grains of characters developed [14], of course, not all can be integrated, therefore, should begin with identifying the values of characters that can be integrated in Basic Chemistry I course through the internalization process. Referring to the definition of the meaning of the character education or configuration code in the totality context of the psychological and socio-cultural process, it grouped in: trick of heart (development of spiritual and emotional), trick of thinking (development intellectual), trick of kinesthetic (development of physical and kinesthetic) as well as trick and kinesthetic (affective and creativity development) [15], it is necessary to analyze the character values, especially the character of science in basic chemistry course.

Basic Chemistry subject as a branch of science knowledge has laboratory activities. It has the potential to embody the character values by implementing the values in learning process of both in the classroom and laboratory. Actually the character values have been encored, but sometimes we do not aware. Character values analyzing is necessary in chemistry subject course that are programmed by the students, especially scientific character value with green chemistry insight to exist of character education. Green Chemistry is a concepts or philosophy or that drive a product or processes design that reduce or eliminate the dangerous substances use and production as defined by Manahan (2006):

"Green chemistry is the practice of chemistry in a way that maximizes the benefits while reducing or at least greatly eliminating its adverse impacts. Green chemistry also call as sustainable practice of the sience of chemical and manufacturing within a framework of industrial ecology in a way that are safe or nonpolluting, sustainable, minimum number of consuming of energy and material resources while virtually no wastes producing " [9].

There are 12 principles of Green chemistry [16] that can be adopted to apply in human attitudes and behaviors as an effort to environment saving. Behaviors to protect environment can be done early by implementing in the education field at almost all levels that can be applied through green education. In this research had been done the scientific character values analysis, mainly by integrating green chemistry principles in scientific character values in order to embody green education through Basic Chemistry learning. The research presented in this article aims to: identify the green chemistry principles that underlying the scientific character value with green chemistry insight; developing alternative learning design for the implementation of the scientific character values with green chemistry insight.

\section{METHOD}

The research design was composed of two main stages. The first stage uses a method of analysis with qualitative systematic review followed by a second phase of developing a learning materials related to the implementation of sound scientific character values with green chemistry insight are tested with pre-experimental design. Data analysis use qualitative descriptive. The procedure begins with systematic review of research conducted by reviewing and analyzing the previous results studies through meta-analysis of the research done by summarizing, reviewing and analyzing the study data from several previous studies [17]. Review conducted to the articles related to the green chemistry principles, green engineering principles and green education. From the results of the mapping study was designed and developed then trial by implementation.

Subjects of this research were students of the Chemistry Department programming Basic Chemistry II course consisting of 22 student class of year 2014 (18 women and 4 men) and 23 student class of year 2015 (17 women and 6 men). Basic Chemistry II coursewas programmed in the second semester by student of chemistry and chemistry education program. Discussing materials of Basic Chemistry II courses are green chemistry topic in the study material Environmental Chemistry. The research target are the principles of green chemistry that underlies the scientific character values and learning design to implement of scientific character value with green chemistry insight and its materials.

\section{RESULTS AND DISCUSSIONS}

\section{A. Data analysis of the scientific character values with green chemistryInsight (SCVGCI)}

Analysis was performed with a systematic review of the results of previous studies related to the green chemistry principles, green engineering principles, and green education. The linkage between green chemistry principles, green engineering principles, and green education, is presented in Table 1. 
TABLE 1. RELATIONSHIP BETWEEN THE GREEN CHEMISTRY PRINCIPLES, GREEN ENGINEERING PRINCIPLES, AND GREEN EDUCATION

\begin{tabular}{|c|c|c|}
\hline $\begin{array}{c}\text { Green } \\
\text { Chemistry } \\
\text { Principles } \\
\text { (GC) } \\
\end{array}$ & $\begin{array}{c}\text { Green Engineering } \\
\text { (G Eng.) }\end{array}$ & $\begin{array}{c}\text { SCVGCI } \\
\text { to embody Green } \\
\text { Education (G Ed.) }\end{array}$ \\
\hline $\begin{array}{l}\text { 1. Prevent } \\
\text { waste } \\
\text { production }\end{array}$ & $\begin{array}{l}\text { 1. Inherent Rather } \\
\text { Than } \\
\text { Circumstantial }\end{array}$ & $\begin{array}{l}\text { 1. Habituation to prevent } \\
\text { of garbage formation in } \\
\text { daily behavior (smart } \\
\text { rubbish) }\end{array}$ \\
\hline $\begin{array}{l}\text { 2. Atomic } \\
\text { Economy }\end{array}$ & $\begin{array}{l}\text { 2. Prevention Instead } \\
\text { of Treatment }\end{array}$ & $\begin{array}{l}\text { ( GC Principle No.1, G } \\
\text { Eng principle No.2) }\end{array}$ \\
\hline $\begin{array}{l}\text { 3. Less } \\
\text { Hazardous } \\
\text { Chemical }\end{array}$ & $\begin{array}{l}\text { 3. Design for ideal } \\
\text { Separation }\end{array}$ & $\begin{array}{l}\text { 2. Habituation to thrift } 1 \text { in } \\
\text { the use of chemicals or } \\
\text { materials (atomic }\end{array}$ \\
\hline Syntheses & $\begin{array}{l}\text { 4. Maximizing of } \\
\text { Efficiency }\end{array}$ & $\begin{array}{l}\text { economy) } \\
\text { (GC Principle No. 2, G } \\
\text { Eng Princinle No } 5 \text { ) }\end{array}$ \\
\hline $\begin{array}{l}\text { Chemicals } \\
\text { Design }\end{array}$ & $\begin{array}{l}\text { 5. Pull of Output } \\
\text { Versus Push of } \\
\text { Input }\end{array}$ & $\begin{array}{l}\text { 3. Using materials that are } \\
\text { safe (GC Principle No. } \\
\text { 3, 4; the G Eng. }\end{array}$ \\
\hline $\begin{array}{l}\text { 5. Use of safer } \\
\text { Solvents and } \\
\text { Auxiliaries }\end{array}$ & $\begin{array}{l}\text { 6. Complexity of } \\
\text { Conservation }\end{array}$ & $\begin{array}{l}\text { principle No.1) } \\
\text { 4. Habituation to save } \\
\text { energy (smart energy, }\end{array}$ \\
\hline $\begin{array}{l}\text { 6. Energy } \\
\text { Efficiency }\end{array}$ & $\begin{array}{l}\text { 7. Durability Rather } \\
\text { Than Immortality }\end{array}$ & $\begin{array}{l}\text { smart mobility, smart } \\
\text { water) } \\
\text { (GC Principle No. 6, G }\end{array}$ \\
\hline $\begin{array}{l}\text { 7. Renewable } \\
\text { Feed stocks } \\
\text { Using }\end{array}$ & $\begin{array}{l}\text { 8. Meet Need, } \\
\text { Minimize Excess }\end{array}$ & $\begin{array}{l}\text { Eng. Principle No. 4) } \\
\text { 5. Be creative in the use of } \\
\text { natural materials that }\end{array}$ \\
\hline $\begin{array}{l}\text { 8. Derivatives } \\
\text { reducing } \\
\text { 9. Catalysis }\end{array}$ & $\begin{array}{l}\text { Diversity } \\
\text { 10. Integration of } \\
\text { Energy and }\end{array}$ & $\begin{array}{l}\text { (GC Principle No. 7; G } \\
\text { Eng principle No. 6, } \\
\text { 12) }\end{array}$ \\
\hline $\begin{array}{l}\text { 10.Designing } \\
\text { for } \\
\text { Degradation }\end{array}$ & $\begin{array}{l}\text { Material Flows } \\
\text { 11. Design for } \\
\text { Commercial } \\
\text { "Afterlife" }\end{array}$ & $\begin{array}{l}\text { 6. Habituation to use } \\
\text { materials biodegradable } \\
\text { easily (GC Principle No. } \\
\text { 10) } \\
\text { 7. Analytical thinking in }\end{array}$ \\
\hline $\begin{array}{l}\text { 11.Pollution } \\
\text { Prevention } \\
\text { by analysing } \\
\text { of Real-time. } \\
\text { 12. Continously } \\
\text { Safer } \\
\text { Chemistry } \\
\text { for Accident } \\
\text { Prevention } \\
\text { [16] }\end{array}$ & $\begin{array}{l}\text { 12. Renewable Rather } \\
\text { Than Depleting } \\
\text { [18] }\end{array}$ & $\begin{array}{l}\text { designing the lead time } \\
\text { work (GC principle No. } \\
\text { 11) } \\
\text { 8. Preventing accidents by } \\
\text { using and treating } \\
\text { materials safely } \\
\text { (GC Principle No. 12) } \\
\text { 9. Care for the environment } \\
\text { (green education) } \\
\text { (Some GC principles } \\
\text { and G Eng. Principles) }\end{array}$ \\
\hline
\end{tabular}

Based on Table 1 the relationship between green chemistry principles, green industry or green engineering, is analogous almost parallel, because the focus and study material is also almost the same. If the principles of green chemistry into force on chemicals, chemical products and processes, then the principles of green engineering also not much different. It could be ingredients in engineering process also uses chemicals. The several of green chemistry principles can be presented in green engineering principles wich identified and may appear in the underlying scientific character values, directly tied to the scientific character values green chemistry insight. Green chemistry principles were identified to underlying of scientific character values can be implemented in the Basic Chemistry learning in order to embody green education.

\section{B. Analysis of learning design of habituation based learning}

An important finding of this study is a relative new learning design is "habituation based learning of scientific character values with green chemistry insight" These finding can be applied as guidance to addressing the problem formulation of alternative learning design for the integrate of several green chemistry principles on scientific character values as an insight. The analysis was performed on the learning syllabus of Basic Chemistry II course to obtain alternative learning design of scientific character values with green chemistry insight. Furthermore, materials of alternative learning design to support habituation based learning was essentially to develop were Semester Learning Design(SLD), Lesson Plan, Student Book and Student Worksheet.

\section{Stages of habituation based learning of integration of green chemistry on scientific character values on Basic Chemistry learning}

Integrating of several green chemistry principleas in scientific character values on Basic Chemistry learning based on habituation as the findings of the first carried out by combining with project-based learning, so that students can engage more actively and explore ideas their creative. So learning designed consist of two meetings, with the first meeting using project-based learning and 2nd meeting with habituation based learning. Project-based learning is modified by adding the beginning and end of the activities. Thus formulated try learning steps as follows: (1) Orientation (2) Task simulation project (planning, implementation, evaluation) (3) Action (practical implementation of habituation: example-repetitionmotivation/reprimand/warning-habituation) (4) Reflection (Results habituation) (5) Evaluation (commitment to followup)

Implementation of project-based learning carried out until the presentation stage of the project plan. At this stage successfully reached the stage of presentation of the design of project task groups at first meeting. Based on the design data of project tasks, students can be used as input to the next meeting with a learning-based habituation.

During the implementation of the learning scientific character values with green chemistry based on habituation supported by some materials that were developed start from draft review, revision and refinement. The study conducted by the research team in a paperless with directly to review on file developed design 


\section{Supporting of implementation of habituation based learning}

Integrating of several green chemistry principles in scientific character values on Basic Chemistry learning by using Habituation Based Learning (HBL) need supporting materials. Efforts made in supporting the learning by: (1) Using the banner of persuasion to implement green chemistry principles in order to embody green education (2) Smart Energy Motion (3) Smart paper Motion Smart Rubbish and development motion, etc.

Implementation of habituation based learning of scientific character with green chemistry insight can be programmed as an action in the broader region, outside the classroom, (in this case the scope of the department of chemistry). Learning by applying habituation requires a relatively long time, so it can be a program at the department level, not quite at the level of the class. Target students are also at the department level. The programs of learning by habituation will be designed and tailored to the department programs. If the learning integrated into a course given at the beginning of the meeting, especially on Basic Chemistry II Lecture. Learning begins at the first meeting, continue to implement of habituation for one semester (12 meeting). Habituation can be implemented on the target class with the understanding and monitoring student behavior at the beginning, during the learning process in the classroom or laboratory experiments, and after the learning process. With integrated on the course, the students were more motivated because it were associated with claim of coursework. Expected next will be characters that are already accustomed.

\section{CONCLUSION}

Identification of green chemistry principles can be obtained several principles underlying the analysis of the character of science, namely: waste prevention, use renewable feedstock, energy efficiency, pollution prevention by real-time analysis and prevention safer chemistry for accident inherently. The scientific character values with green chemistry insight as the results of the mapping are: honest, curiosity, environment caring (such as smart energy, smart mobility, smart water, or smart rubbish), creative and saving (use of natural product for the human benefit and chemistry learning), and others. Implementation of the principles of green chemistry on the scientific character values with green chemistry integrated in Basic Chemistry course can be implemented with alternative learning such as Project Based Learning by giving the project tasks to the students.

Stages of learning can be accomplished by integration on Basic Chemistry course in order to embody green education. Activities that can be implemented ranging from classroom learning, the implementation of the tasks a student project, which is expected to develop into habituation. Learning in the classroom can be done well.
Characteristics of project-based learning can come up creative ideas of students in the implementation of integration of several green chemistry principles in scientific character values.

\section{ACKNOWLEDGMENT}

The authors full appreciate and would like to thank to DRPM, Universitas Negeri Surabaya and Institution of Research and Community Service (LPPM), for the support of the funding from BOPTN of Universitas Negeri Surabaya and Ministry of Research Technology and Higher Education by DRPM. We also appreciate and thank to Staff and Students of Chemistry Department who was involved in this research.

\section{REFERENCES}

[1] M. Karpudewan, W.M. Roth, and D. Sinniah. "The role of green chemistry activities in fostering secondary school students' understanding of acid-base concepts and argumentation skills", Chem. Educ. Res. Pract., 17, pp: 893-901, 2016.

[2] N.H. Ramli, M.H. Masri, M.Z. Haji, M. Taib, \&N.A. Hamid, "A comparative study of green school guidelines". ASEAN Conference on Environment-Behaviour Studies, Bangkok, Thailand, 16-18 July 2012

[3] A. Pellegrino, S. Cammarano, V. Savin, Day lighting for Green schools: a resource for indoor quality and energy efficiency in educational environments. $6^{\text {th }}$ International Building Physics Conference, IBPC 2015. Energy Procedia 78, pp: 3162-3167, 2015

[4] S. Yilmaz, H. Binici, H.R. Ozcalik,."Energy supply in a green school via a photovoltaic-thermal power system". Renewable and Sustainable Energy Reviews 57, pp: 713-720, 2016.

[5] B. Debnath, R. Baidya, N.T. Biswas, R. Kundu, S.K. Ghosh, "E-waste recycling as criteria for green computing approach: analysis by QFD tool". Book Chapter: Computational Advancement in Communication Circuits and Systems", Proceedings of ICCACCS, 2014.

[6] B. Cao, S. Wang, "Opening up, international trade, and green technology progress". Journal Cleaner Production, 2016,http://www.sciencedirect.com/science/article/pii/S095965261631 $\underline{3105}$

[7] L.H. Bodlalo, M. Sabbaghan, S.M.R.E. Jome, "A comparative study in green chemistry education curriculum in America and China", . Procedia -Social and Behavioral Sciences 90, 2013, pp: 288-292.

[8] A. Zsoka, M.Z. Szerenyi, A. Szechy, T. Kocsis, "Greening due to environmental education? environmental knowledge, attitudes, consumer behavior and everyday pro-environmental activities of Hungarian high school and university students". Journal of Cleaner Production 48, 2016, pp: 126-138.

[9] S.E. Manahan, Green Chemistry and the Ten Commandements of Sustainability. $2^{\text {nd }}$ ed, Columbia: ChemChar Research, Inc., 2006.

[10] M. Karpudewan, Z. Ismail, \&W.M. Roth, "The efficacy of a green chemistry laboratory-based pedagogy: changes in environmental values of malaysia pre-service teachers". International Journal of Science and Mathematics Education, 2012, 10, pp: 497-529.

[11] M. Samani\&Hariyanto. Concept and Model of Character Education(Konsep dan Model Pendidikan Karakter). Bandung: PT. Remaja Rosda Karya, 2012

[12] Mitarlis, Y. Bertha, H. Rusly. “Analysis of Green Chemistry's insightful Science Caharacter Value in Basic Chemistry Lectures in the Framework of Creating Green Education (Analisis Nilai Karakter Sains Berwawasan Green Chemistry Pada Perkuliahan Kimia Dasar Dalam Rangka Mewujudkan Green Education)”. Proceeding SNKPK vol.1., 2015, ISBN: 978-602-14397-1-5 Seminar Nasional Kimia dan Pendidikan Kimia 2015. Jurusan Kimia FMIPA Universitas Negeri Semarang.

[13] Mitarlis. "The Role of Basic Chemical Practicum Activities I Mixed Separation Materials in the Framework of Achieving Character Values for Unesa Chemistry Student with Integrated Models (Peranan Kegiatan Praktikum Kimia Dasar I Materi Pemisahan 
Campuran dalam Rangka Pencapaian nilai-nilai karakter bagi Mahasiswa Kimia Unesa dengan Model Terintegrasi)". Prosiding Seminar Nasional Kimia Unesa. ISBN:978-979-028-550-7 Pebruari 2012.

[14] Kemdiknas. Guidelines for Character Education Implementation (Pedoman Pelaksanaan Pendidikan Karakter). Jakarta: Puskurbuk, 2011.

[15] Kemdiknas. Design of Character Education (Desain Induk Pendidikan Karakter). Jakarta, 2010.

[16] P.T. Anastas, and J.C. Warner, Green Chemistry: Theory and Practice.New York: Oxford University Press. By permission of Oxford University Press, 1998.

[17] D.J. Bowen, and Neill,"A meta-analysis of adventure therapy outcomes and moderators". The Open Psychology Journal, 2013, 6,pp: 28-53.

[18] P. Anastas, F.W. Black, T. Masciangioli, E. McGowan, and L. Ruth, Exploring Opportunities in Green Chemistry and Engineering Education. Wahington D.C.: The National Academies Press, 2007. 